\title{
Religious Plurality from the Perspective of Islamic Religious Education
}

\section{Introduction}

The complexity and multifaceted character of creation could lead us to expect that people - an important part of this creation - see plurality as an enrichment. Nevertheless, contrary to this well-intended assumption, reality often looks quite different. For various reasons, plurality - particularly in its religious and worldview manifestation - is viewed increasingly as an artificially induced situation that is owed to a wrongly understood tolerance, a situation that threatens one's own cultural and religious identity and therefore must be overcome.

One can see how non-intuitive a respectful approach to plurality or religious and worldview diversity is can also be seen in the fact that it is also being increasingly rejected in liberal democratic society. This again indicates that an attitude that guarantees a peaceful and respectful co-existence in a pluralist society can only be appropriated through reflection and self-control and must then be constantly put into practice.

An essential role in the shaping of a respective attitude to plurality naturally belongs to religions, which are instructed to encounter the growing religious and worldview diversity in our society with new and theologically grounded approaches. In contrast to the apologetic assertion that religions as such are pluralist in themselves, one can say that

\footnotetext{
[w]ithin each of the major religions we find a range of different approaches to religious plurality, both in terms of how to understand it doctrinally and how to relate to it practically. (Schmidt-Leukel, 2017, 1)
}

To conclude from this that religions fundamentally lack an ability for plurality would be almost as wrong as insisting on the opposite. To be sure, it is not a commandment simply written down in the sources, simply waiting to be discovered. On the contrary, a special mindset and a hermeneutical ability are needed to base a religious and worldview pluralism on these sources from a religious or theological perspective. Numerous examples of religious intolerance towards those of other faiths and dissidents in history and in the present reveal the ambivalent nature of religions. At the same time, they indicate the necessity of a suitable, contextual approach to the religious sources that do no more than open up the possibility of developing a respectful attitude toward the religious and worldview plurality based on one's own sources. 
Islamic theology and religious education cannot avoid this task of course. Particularly in religious and worldview pluralist societies like the European one, theological and religious educational approaches are needed on whose foundation plurality can be understood as a natural enrichment and an internal theological perspective can be grounded. It is true that - due to the increasing interreligious collaboration in recent years as well as the increase in religiously motivated violence by radicalised Muslim youth - the question of a respectful approach to religious and worldview plurality is also being introduced more and more by Muslims themselves, and classical positions in Islamic theology that stand in the way of plurality are being re-examined (Wielandt, 2007). Nonetheless, there are still no well thought out theological approaches that have been formulated - a condition that can turn out to be disastrous for Islamic religious education (Amirpur, 2015, 168). However unimportant the consequences may be for societies that are culturally and religiously and ideologically homogenous, for a pluralist society, such approaches are a "necessary condition for survival" (Peukert, 2004b, 364). Precisely in the Austrian context in which confessionalcollaborative religious education models are being tried out and theological and religious educational training is done interreligiously in many places, there would be hardly any prospect of success without a respectful attitude towards religious and worldview plurality (Sejdini, Kraml \& Scharer, 2020).

Accordingly, one of the greatest challenges for Islamic theology and religious education in the European context consists in supplying the stated lack - including through the development of new approaches that enable and promote a respectful approach to diversity. Here the cultivation of such an attitude - right in the teacher education programme and religious education - is anything but an easy task: this process is nonetheless influenced by many factors that follow different, indeed even contradictory, interests and logic. For example, in addition to institutional stipulations, various epistemological, theological, pedagogical, and especially anthropological assumptions and approaches based on different premises enter into theological and religious educational approaches.

Because these approaches, which stamp the attitudes to plurality as a whole, also provide information on the ability of theological and religious educational approaches to promote diversity, they should be assessed first. Given that we cannot, for various reasons, look at all approaches, we will focus in this essay on the theological conditions for a pluralist Islamic education programme that can be a viable foundation for a respectful approach to religious and worldview plurality. To that end, the present theological approaches to religious and worldview plurality will be briefly presented in the next section. After that, I will attempt to explain such plurality from the perspective of Islamic theology. Finally, 
I will present the necessary conditions for such an approach to religious education.

\section{Approaches to the Religious Other}

The question of how to deal with the other, the stranger means that there is no community that does not see itself as confronted by great challenges. This also obtains for the religious context. Given the increase in religious plurality and the concomitant rise in competing religious worldviews, religions are required to interpret - from their own perspective - and to define religious plurality and their mutual relations. This task has indeed, according to Christian Danz, gained urgency through the "modernisation moves of the last 200 years" (Danz, 2010, 23) and the subsequent globalisation, but it is not, however, new. Religions have been guided right from the start by the need to interpret (anew) their cultural, religious, and political environments and to place themselves in relation to it. Accordingly, this theme, at least in the Islamic context, already penetrated the sacred scriptures and the early modern theological discussions and treatises. The statements in the scriptures and views of the scholars are predominantly related of course to those religious traditions and groups that were present in the immediate cultural and geographical environment of their context of origination. This has changed with time. On the one hand, the focus, which was originally directed at the immediate environment expanded; on the other hand, various, even contradictory, opinions arose within the religions themselves on how to deal with religious diversity (Schmidt-Leukel, 2019, 14). Thus arose a plethora of different, diverging approaches with respect to orientation. In the modern period, the first attempts at a categorisation or defining of new relations between one's own and other religions occurred in the Christian context. According to Danz, they naturally dealt first with the relation between Christianity and the other religions because

above all the transformation process, to which Christianity and Christian theology have been subject since the European Enlightenment ... also [led] increasingly to the insight that the traditional models of the relation between Christianity and the non-Christian religions are inadequate. (Danz, 2005, 13)

This original Christian 'initiative' has in the meantime been widely imposed as a model for defining relations in other religious contexts as well. A significant part in this development was played by Alan Race and Gavin D'Costa, both students of John Hick. Race devoted himself to this theme in his work published in 1983, 
Christians and Religious Pluralism: Patterns in the Christian Theology of Religions. In 1986, D'Costa published his Theology and Religious Pluralism: The Challenge of Other Religions. Since then, in the words of Perry Schmidt-Leukel, one of the most significant representatives of the pluralist theology of religions in German-speaking areas, "a typology has spread around the globe that lists three different options for a religious interpretation of religious diversity: exclusivism, inclusivism, and pluralism" (Schmidt-Leukel, 2017, 3).

Even if this typology is explained in different ways, partially modified and criticised (Schmidt-Leukel, 2005, 61), it still forms the foundation for all categorisation models of the attitude of religions to religious plurality. ${ }^{1}$ We will give an overview of this typology below, in which the focus will be on pluralism, given that this essay explores the question as to whether - and, if so, how - Islamic theology allows the development of a position of religious pluralism.

\subsection{Exclusivism}

The first of the three elements of this typology is exclusivism, which rests on the assumption that one's own religion is superior to all others. According to Danz, the exclusivist model is a

position, option, or attitude ... guided by the conviction that there is only one true religion and, consequently, all other religions are mere superstition, illusion, or false religions. (Danz, 2005, 57)

Even if the exclusivist model is nuanced in certain ways (Schmidt-Leukel, 1993, 167), it still stresses the principle that "the communication of salvific knowledge/ revelation of a transcendent reality exists only in one religion" (Schmidt-Leukel, 2006, 16).

For demonstrable reasons, the characterisation as exclusivist applies to most of the classical theological approaches. On the one hand, the exclusivist position promoted the development of one's own and independent identity; on the other hand, it served - beyond the origination phase - to legitimate the religious tradition. Particularly for Christianity and Islam, this aspect was of enormous significance from the start because both, despite their unanimous appeal to the Abrahamic tradition, distinguished themselves from Judaism on central points.

This approach is problematic in many respects. The absolute truth claim that is immanent to it and the accompanying limitation of the possibility of sal-

1 For further details, see Schmidt-Leukel 1993. 
vation to one's own religious tradition practically excludes a respectful interreligious dialogue on an equal footing. Moreover, by making its own internal perspective absolute, this model contradicts the elusiveness of absolute transcendence, which is anchored in various forms in the Abrahamic tradition. And finally, the exclusivist approach "clearly undermines the credibility of each religious perspective" (Schmidt-Leukel, 2017, 2f.) and thus turns out to be a precursor of naturalism, which, in distinction from exclusivism, does not concede a special position to any religion but sees a plurality of deception and error in the plurality of religions (ibid., 2017, 6).

Even if the exclusivist approach is finding less and less of a reception at present - especially in theological circles - such a view is still widespread, especially in conservative and fundamentalist circles. At first glance, this primarily salvation-centred approach has no great significance. In religiously pluralist contexts, however, it can have thoroughly fatal consequences. Johanna Pink gets to the heart of this when she writes:

\footnotetext{
If an adherent of a religion is convinced that the adherents of all other religions are threatened with hell in the hereafter, then this may thoroughly influence his attitude in this life to these people, whether this attitude is expressed in offensive mission activity or in derogation of these people. In this respect, the relevance of the discussion on the question of admission to paradise cannot be underestimated. (Pink, 2011, 59f.)
}

\subsection{Inclusivism}

Danz writes:

Inclusivism and superiorism characterise a religious and theological position, option, or attitude in which it is assumed that there are indeed several true religions, but one religion is more true than the others. (Danz, 2005, 62)

The inclusivist model is defined in general, according to Schmidt-Leukel, "by reference to and in demarcation from exclusivism" (Schmidt-Leukel, 1993, 167). Namely, inclusivism grants other religions a fundamental validity (SchmidtLeukel, 2006, 16) - unlike the exclusivist model - and thus in that respect represents a considerable advance by not fundamentally denying the possibility of salvation outside its own religion. Regardless of this essential distinction from the exclusivist approach, inclusivism - and all its subgroups (Schmidt-Leukel, 1993, 167) - holds that the fullness of salvation is only found in one's own religion - whereby all other religious traditions necessarily turn out to be inferior (Schmidt-Leukel, 2005, 25). The goodness of the experiences of salvation in 
other religions is measured in terms of its agreement with what one's own tradition promises. The greater this agreement is, the more the other religion can be said to be 'true'. In contrast, everything in which other religions deviate from one's own is interpreted as "an expression of its inadequacy" (Schmidt-Leukel, 2006, 26).

The original advantage over exclusivism is relativised to a certain extent, and it is clear what unites the inclusivist and the exclusivist positions despite all their essential differences: the inability to cultivate a respectful view of religious plurality because the generally negative attitude of these approaches to other religions leads them to see religious diversity as a shortcoming and not as a natural enrichment. This attitude towards religious plurality leads to the contempt of other religious beliefs and excludes any respectful encounter beforehand. According to Danz, inclusivism is, in the end, nothing more than "a kind of rinsed exclusivism" that attempts "to impose an interpretation of one's existence on someone of another faith that does not correspond with the latter's own self-awareness" (Danz, 2005, 70).

If one follows Schmidt-Leukel, the proposed triad is suited not only for theological analyses. It is also "logically comprehensive and inevitable' so that 'the search for alternative typologies ... is pointless and commitment to one of the three possibilities is unavoidable" (Schmidt-Leukel, 1993, 163). The last model described by Schmidt-Leukel on the relation is, according to this triad, the pluralist model, which - as the model at the basis of this essay - will be the subject of the next section.

\subsection{Pluralism}

Like the inclusivist and the exclusivist positions, the pluralist approach - known in the literature as 'a pluralist theology of religions' or 'religious theological pluralism' - pursues various approaches to religious plurality (Danz, 2005). The pluralist theology of religions can be traced back to the English philosopher John Hick (d. 2012), who, in addition to being a professor of philosophy of religion, was also an ordained minister in the Presbyterian Church of England. His own originally conservative evangelical orientation experienced a radical change through his encounter with other cultures and religions in his hometown of Birmingham. Furthermore, his views were decisively influenced by the theses of the famous Islamologist, theologian, and religious studies scholar, Wilfred Cantwell Smith (d. 2000) (Schmidt-Leukel, 2005, 20 f.). Hick's pluralist approach influenced numerous theologians in various countries, religions, and confessions 
and up until the present constitutes the foundation and starting point of many similar reflections and approaches.

With respect to content, the pluralist model shares the inclusivist view that there is also a possibility of salvation outside one's own religion; in distinction from inclusivism, however, it rejects the assertion that salvation "is achieved or achievable in its highest degree in one single religion" (Schmidt-Leukel, 1993, 168). Following Hick, in distinction from inclusivism and exclusivism, pluralism

designates a specific theory and evaluation of religious diversity. This theory first assumes that religious truth exists - and in a sense must exist - in a diversity of forms, which are then assessed as equally valid despite their being different (Schmidt-Leukel, 2017, 1)

The main concern of the pluralist theology of religion consists essentially in placing the perception of religious plurality as an enrichment and not as a shortcoming on a solid theological footing. It sees the recognition of the equality and equal rights of every religion concerning what is held as true, authentic, and salvific for its adherents to be a basic condition for this. It advocates the belief that a religion's salvific power does not depend on its doctrinal formulas but on "the spiritual state, or existential condition, constituted by a person's present response to the ultimate divine Reality" (Hick, 1985, 29). Hick defines the positive openness to this reality as "the transformation of human existence from self-centredness to Reality-centredness" (ibid.). In other words, "God alone ... should be at the centre of religions" (Bernhardt, 1993, 146). The orientation to God is what constitutes faith - independent of the differences between the religious traditions; religions in themselves, however, are "cumulative traditions" (Hick, $1985,30)$ that arose in various contexts and are distinguished from each other in a number of aspects - each in the attempt to provide an answer to the problem of transcendence. This perspective prohibits any religious tradition from elevating itself above the others because every religion can lead its adherents to this transformation, for "salvation ... is not necessarily restricted within the boundaries of any one historical tradition” (ibid., 32).

This attitude should on the one hand reinforce the credibility of the different religions but on the other it should also smooth the road to a substantial interreligious dialogue. Important here above all is the awareness that this pluralist attitude "can be developed only from within the different religious traditions" (Schmidt-Leukel, 2017, 1).

To base a religious pluralist approach on one's own religious tradition is, as already maintained above, not an easy undertaking - not least of all because this approach has not only been encouraged; it has also been critiqued a great deal (ibid., 28). In particular, the pluralist theology of religions has been subject- 
ed to the objection that the equality of the different religions leads to relativism. Schmidt-Leukel replies with the clarification that the pluralist position also leaves no doubt

that not everything that is claimed and believed in religions can be equally true.... What pluralists advocate, however, is that the various ideas of transcendental reality that we find in the major religious traditions can be understood as equally valid under two conditions. (Schmidt-Leukel, 2006, 21)

The point here is not to even out the differences but to interpret them in such as way "that they can be understood as compatible in principle or even as complementarity" (ibid.).

Paul F. Knitter, another important advocate of pluralist theology, also emphasises that it is not a matter of declaring all doctrines and actions of all religions as equally valid but the recognition "that all participants in the dialogue must have equal rights to be able to conduct an actual dialogue" (Knitter, 1998, 77). For him, dialogue is the "highest good" and the "normative value" (ibid., 75f.) in the pluralist theology of religions.

Independent of the objections raised against pluralist theology, it is indisputable that only this approach to religious plurality is able to recognise the fact of this enrichment and provide a stable foundation for interreligious dialogue and exchange grounded in mutual respect. For this dialogue to occur, the attempt to ground the religious pluralist approach theologically as a possible or favoured interpretation out of the various religious traditions must succeed. Whether - and, if so, how - this is possible from the Islamic perspective will be investigated in the next section, taking all possible consequences for Islamic religious education into account.

\subsection{Islamic Approaches to Religious Plurality}

The engagement with religious plurality or with other - in particular the Abrahamic - religions has a long tradition in Islam, going back to the time it originated. Muslim scholars began quite early to occupy themselves with this theme, whereby a series of different views on religious plurality emerged over the course of time. Other than often assumed, there is no shared, consistent Islamic position (Hartmann, 2006, 131). In all the generalisations suggesting such unity, to which all Muslims are bound, we encounter inadmissible simplifications that mask the internal Islamic plurality and promote the emergence of biased images of Islam that contradict reality (Zirker, 1996, 190). 
Furthermore, the circumstance that Muslim scholars appeal to the wellknown Islamic sources, especially the Qur'an, to ground their positions on religious plurality, should not lead us to lose sight of the fact that there is no concrete approach to religious plurality here either. To the contrary, the numerous passages in the Islamic sources can be interpreted in completely different ways. ${ }^{2}$ That also applies to the Qur'an, the primary source of Islam, whose partly ambivalent statements allow different options with respect to determining the relationship to other religions. This is connected primarily with the fact that the Qur'an came into existence successively over a period of more than twenty years and in relation to its context, which needs to be considered in understanding the Qur'an's central meaning.

The broad range of meanings that emerge because of the ambivalent character of Qur'anic statements on religious plurality ranges from various nuanced exclusivist and inclusivist approaches to those that can be viewed as pluralist (Pink, 2011, 60). In view of this, there can be no talk of the one 'genuine Islamic' approach. Rather, every opinion and every view should be evaluated concerning its advantages and disadvantages as a possible approach, and it should be kept in mind that they are all subject to contextual stamps and therefore without exception perspectival and fragmentary (Hanafi, 2013, 30). This does not mean that all views are equally important and that none deserve to be rejected; it does mean, however, that, despite the differences or contradictions between them, we should not attempt to deny 'the Islamic as such' in them. For our purposes, we do not need to determine which of these approaches are authentic - which would be very difficult - but to understand the circumstances under which they arose, which arguments they follow, and what the consequences for the present are.

Consequently, this essay should also be understood as an attempt to present that aspect of plurality in various approaches in the Islamic context and to weigh the advantages and disadvantages. This should be done to make both the opportunities and the limits or challenges visible that open up in the search to deal with worldview and religious plurality in the Islamic context.

It should also be mentioned that, as an approach, religious theological pluralism arose not least because of the changes in the modern period. To search for a similar approach in the Middle Ages would be anachronistic and not expedient. And this is not because there were no approaches and behaviours geared towards the peaceful co-existence of different cultures and religions. Rather,

2 "Islam could be both 'tolerant and intolerant', and both to an extreme degree" (Hartmann, 2006, 147). 
the approaches correspond with the spirit of the times and are fundamentally different from the pluralist approach proposed here (Al-Azmeh, 2009, 10).

Regardless of the different views on the proper approach to plurality in general and to other religious traditions in particular, every view that can be called 'Islamic' needs to be legitimised by the Qur'an. Because the Qur'an, as already stated, does not contain any concrete approach but instead presents numerous statements on this theme, any discussion of this theme must assess the most important Qur'anic statements.

\section{The Plurality Willed by God}

In addition to divine unity (tawhid), the Qur'an also thematises the plurality of creation: just as unity and uniqueness belong to the essence of God, so plurality belongs to the essence of creation. This plurality also extends to human beings as an essential part of creation. Despite their common origins, they are stamped by cultural, ethnic, and religious diversity. A central Qur'anic statement that brings the ethnic and cultural plurality to expression as a divinely intended state can be found in Q 49:13. There we read:

O men! Behold, We have created you all out of a male and a female, and have made you into nations and tribes, so that you might come to know one another. Verily, the noblest of you in the sight of God is the one who is most deeply conscious of Him. Behold, God is all-knowing, all-aware. (Q 49:13)

Already in this verse, which is not only a clear confession of plurality but also communicates a rejection of any claim to superiority over other cultures, the Qur'an provides a stable argumentative foundation that not only permits but even commands that plurality be understood and cultivated as a divinely willed and irreversible state of nature.

Although the focus here is on cultural and ethnic plurality, evidence can be produced via numerous Qur'anic verses that God also at least permits religious plurality, which indicates that this is to be viewed as a natural phenomenon. Several verses (Q 5:48; 6:107; 10:99; 11:118; 16:93) serve as important supports of this assumption and together point out that God, if he had so willed, could have joined humankind into one single community or could have compelled them to believe. Because this contradicts the meaning of faith - which consists above all in people having free will and consciously choosing faith - God refrained from such intervention and admonished those who seek to impose faith on others that this is neither possible nor the intention of the creator. 


\subsection{The Religious Others}

The Qur'anic occupation with other religions did not occur in a vacuum but was embedded in the cultural context in Mecca in the seventh century in which it arose and in which it had influence. Consequently, the question of the appropriate attitude to other religions was at first limited to those religions or faith communities that were known in the Qur'an's context of origination (Hermansen, 2016, 46). This included on the one hand polytheism and on the other Judaism and Christianity, as well as Zoroastrianism (Zirker, 1996, 191). Whereas the polytheists are invited to turn from their worship of many gods and to believe in the one God, the adherents of Judaism and Christianity are called, as adherents of the same monotheistic tradition, to a common confession in the one God (Q 3:64). Adherence to the common Abrahamic tradition, to which various verses (Q 2:136; 3:84; 5:48) refer, led to an intense engagement with Judaism and Christianity. That is why there are numerous Qur'anic verses that either thematise both religions - summarised under the designation ahl al-kitab, i.e., the socalled people of the book or receivers of revelation - or each religion individually (Pink, 2016). Against this background, inherent tendencies of the Qur'anic perspective will be explained below by means of central Qur'anic verses. These verses have to do with the attitude towards other religions in general and Judaism and Christianity in particular.

We should first of all recall that the statements on Judaism and Christianity found throughout the Qur'an are neither chronologically nor systematically ordered. Moreover, many statements are quite ambivalent and bound to their immediate context, which hampers the determination of their precise significance and scope. These circumstances favoured the rise of different, even partly contradictory, views on what form to give to the relation to other religions (Sejdini, 2017b).

The central texts for an exclusivist attitude in the Muslim context are the following: "Behold, the only (true) religion in the sight of God is (man's) self-surrender unto Him" (Q 3:19) and "For, if one goes in search of a religion other than self-surrender unto God, it will never be accepted from him, and in the life to come he shall be among the lost” (Q 3:85). These and similar Qur'anic statements (Q 5:3) led Muslim scholars to see in exclusivism the only possible approach to other religions that was legitimated by the Qur'an. Accordingly, non-Muslims are in principle excluded from the possibility of salvation (Koçyiğit, 1989). This widespread assumption found general acceptance - with a few exceptions in Islamic mysticism - so that discussions focused more on the rights and duties of those of other faiths than on whether they enjoyed the possibility of salvation (Pink, 2011, 59). 
In addition to these Qur'anic verses, which - at least at first glance - exclude the prospect of salvation outside of Islam, there are others that support a more pluralist approach. These include primarily a verse that appears in two places (Q 2:62; 5:59) in identical words. There we read:

VERILY, those who have attained to faith (in this divine writ), as well as those who follow the Jewish faith, and the Christians, and the Sabians - all who believe in God and the Last Day and do righteous deeds - shall have their reward with their Sustainer; and no fear need they have, and neither shall they grieve. (Q 2:62)

These verses are the most important references for inclusivist and pluralist approaches in Islamic theology. For Muhammad Asad (d. 1992), they unmistakably state that salvation does not depend on religious affiliation but on the fulfilment of the following three conditions: "belief in God, belief in the Day of Judgment, and righteous action in life" (Asad, 2008, 21). Moreover, Asad derives from them a clear rejection of any exclusivist interpretation that wants to connect the possibility of salvation to adherence to a particular religious tradition.

Qur'anic statements like those introduced here as exemplary have thus, due to their ambivalence and ambiguity regarding the approach to the religious other, bestowed complexity on the theme. This complexity is such that the Qur'an continues to be a source of controversy among Muslim scholars and a lasting source of differing opinions. The differences between the Islamic exclusivists and the pluralists did not only result from the fact that they, as stated, find support for their views in different Qur'anic verses. Rather, they also result from the fact that they interpret verses that support the other side differently in order to bring them into harmony with their own claims. Thus, for example, Muslim pluralists defend the view that the word islam, which appears in both versions and serves as the foundation for the exclusivist attitude does not refer to institutionalised Islam. Rather, it means the submission to God that transcends religious confessions, whereby these verses acquire a completely different meaning. Accordingly, it is not institutionalised Islam that is the object of God's good pleasure but devotion to him. Muhammad Asad argues similarly when he translates the Arabic word islām in both cases by "self-surrender unto God" (ibid., 95).

Again, Muslim exclusivists are opposed to the decidedly pluralist attitude advocated in the verses Q 2:62 and 5:59. They endorse the majority of commentators on the Qur'an who argue against this unequivocalness and instead

either say that by Jews, Christians, and Sabaeans here are meant those who have actually become 'Muslims' - which interpretation is clearly belied by the fact that 'Muslims' constitute only the first of the four groups of 'those who believe' - or that they were those good 
Jews, Christians, and Sabaeans who lived before the advent of the Prophet Muhammad (PBUH) - which is an even worse tour de force. (Rahman, 1980, 115)

The ambivalence of the Qur'anic statements is not limited to the fact that the wording in specific verses apparently contradicts the wording in others. This ambivalence also increases through the fact that there are apparently unequivocal verses, such as those cited above, that can be interpreted in different ways. Aside from political interests, there is an important reason in this double ambivalence for the fact that entire regions of the world that were under Muslim dominion have experienced periods characterised by tolerance towards those of other faiths and periods in which repression was practised (Sachedina, 2019, 70). Thus, a progressive exegesis was possible that permitted the expansion of the privileges granted to Jews and Christians to other religions not mentioned in the Qur'an (Zia-ul-Haq, 2010, 513). On the other hand, an exegesis was also possible in which entire Qur'anic verses that speak of respect towards and appreciation of those of other faiths are declared abrogated by one single verse, the socalled sword verse ( $Q$ 9:5), and the pluralist approach is denied any foundation in the Qur'an (Öztürk, 2016).

Thus, neither the numerous Qur'anic verses that simply argue for a respectful approach to those of other faiths nor the countless examples of lived Muslim tolerance found in history establish a tendency in this direction. In many areas and regions today, one can observe a stagnation or even a regression beyond the achievements of earlier, more plurality-friendly epochs (Aydın, 2019, 262).

This possibly also has to do with the far-reaching and not very reflective continuation of approaches in classical Islamic hermeneutics as well as Islamic jurisprudence, both of which enjoy dominant positions in the Islamic theological disciplines. As progressive as these approaches may have been in a certain period, they suffer from the shortcoming of, at best, professing a toleration of others. This was a tolerance that was accorded certain religious groups under specific conditions, but not an understanding of plurality that implied equal treatment and respect. This attitude - progressive for relations at the time - towards people of other faiths, which was acknowledged in general (Wielandt, 2007, 56), is an important indication of the ambivalence of Muslim sources and the flexibility of Muslim scholars in dealing with this theme. Moreover, it suggests that a hermeneutic operative in light of this progressive spirit would also be able today to develop new approaches that could encompass plurality, which are both nourished by the Muslim tradition and takes the current spirit of the times into account. This would also be in harmony with the well-known legal maxim from the Ottoman period, according to which it cannot be denied that rules also change with the times (Zia-ul-Haq, 2010, 501). 
This progressive view and the requirements of the present have, pursuant to the general developmental process of pluralist approaches, encouraged a considerable number of Muslim scholars to work on theological approaches - as they occasionally did in the classic Islamic period. These approaches are intended to provide a solid basis for a pluralist Islamic theology. The central thesis of Muslim pluralists will be explored briefly below.

\title{
3.2 Muslim Voices on Plurality
}

The attempt to determine the relation to other religions, especially Judaism and Christianity, was already present among Muslims right from the start for the reasons cited above. The focus was then directed, according to Pink, at the

\begin{abstract}
status of non-Muslims in Muslim-majority societies, freedom of religion, and ğihād - thus questions of co-existence at the time between Muslims and non-Muslims. One aspect that has been almost always concealed is, however, the theological classification of non-Muslims. (Pink, 2011, 59)
\end{abstract}

Given political developments as well as the growing religious and worldview plurality, primarily as a consequence of the Muslim presence in non-Muslim majority countries, the focus of the debate has changed, partly under duress. Under the influence of the budding pluralist approaches in Christian theology and a heightened awareness of the inadequacy of exclusivist attitudes, approaches also emerged in Islamic theology, if somewhat delayed, that can also be classified as pluralist. $^{3}$

Even if such approaches in Islamic theology are relatively new, the number of publications on this theme have the meantime become incalculable, which is why we can only look at a few central figures and approaches here. Instead of exploring the various nuances among Muslim pluralists, in the following section I will explain those approaches that display a minimum consensus that the promise of salvation cannot be limited to Muslims alone.

Among the most important Muslim intellectuals who advocate pluralist positions and attempt to ground these in Islamic sources are Fazlur Rahman (d. 1988), Nurcholish Madjid (d. 2005), Hasan Askari (d. 2008), Asghar Ali Engineer (d. 2013), Süleyman Ateş (b. 1933), Mehmet Aydın (b. 1943), Mahmoud M. Ayoub (b. 1935) und Farid Esack (b. 1959), to name only a few (Amirpur,

3 For an overview of the theme of Islamic pluralism in the German language, cf. Ernst Fürlinger and Senad Kusur (2019); Schmidt-Leukel (2019); Amirpur (2015); Pink (2011). 
2015, $167 \mathrm{f}$.). Katajun Amirpur summarises the hypothesis of Muslim pluralists, which they derive from the Qur'an, as follows:

First, the confirmation of a general possibility of salvation for all those who live in the true fear of God and accountability, even if they are not Muslim (Q 2:62, 112, 113; 5:72; 20:112); second, the conviction that God has not left any people without the necessary revelation or prophetic right guidance ( $\mathrm{Q}$ 5:19, 48; 10:47; 14:4; 35:24); third, the confession of the transcendence of God that goes beyond all human forms of expression (Q 17:43; 37:180; 112:4). (Amirpur, 2015, 168)

In addition to general Qur'anic frameworks, reference is made to the following basic assumptions in grounding a pluralist attitude.

The most important foundation for the Muslim pluralists is their broad understanding of Islam. In contrast to the exclusivists who, through referring to the Qur'anic verses 3:19 and 3:85 already mentioned above, limit the possibility of salvation to institutionalised Islam, pluralists advocate the view that the word islam in these verses does not refer to a specific religion - in this case institutionalised Islam - but to a general attitude understood as devotion to God (Izutsu, 2008, 217f.). Consequently, every person who believes in the uniqueness of God and serves him is a muslim at heart, even without explicitly confessing institutionalised Islam (Ateş, 1998, 11). In the words of Süleyman Ateş, the respected Turkish exegete and former head of the Turkish Diyanet (Department of Religious Affairs), islam is

not only the designation for the religion that the Prophet Muhammad proclaimed, but Islam is the common name of the religion that God proclaimed to people from Adam to the Prophet Muhammad. (Ibid., 24f.)

Ateş does not see the distinction between the individual religions in the essence of the revelations that consist in serving God and doing good deeds. He finds that distinction, rather, in human nature (ibid., 13).

Nurcholish Madjid also argues in a similar fashion when he distinguishes between a 'universal way' that all religions share and a 'particular way' that differs from religion to religion. He therefore argues for maintaining the idea of universality, while in practice using the various forms and making them productive for the common good (Madjid, 2005, 212). Mahmoud M. Ayoub endorses this view with the remark that the meaning of the concept islam is not exhausted in the designation of a specific religion: "The term islam, in this sense, applies to the heavens and the earth and all that is in them, to humankind and to everything that God created" (Ayoub, 2016, 278f.). This view, which constitutes the common basis for Muslim pluralists, paves the way to the recognition of different 
experiences of the transcendent as potential ways of salvation and to taking up a respectful dialogue in which the primary concern is to understand the transcendental dimension of the other.

As a further argument for the separation of institutionalised Islam from islam in the sense of devotion to God, the Muslim pluralists also use the verses Q 2:62 and Q 5:59, in which, as already mentioned, the possibility of salvation is extended to other religions, especially Judaism and Christianity. Appealing to the Qur'anic indication that God had turned to people over the course of time via countless prophets (Q 16:36), who communicated the message of God in their respective languages ( $Q$ 14:4), they advocated the view that the core message was the same among all (Ateş, 1998, 17), even though the form differed according to the context. Syed Vahiduddin also endorses this idea when he says: "In other words, din in its essence is the same, whereas the Way ( $\operatorname{sharī}^{\prime} a$ ) differs from period to period of religious history" (Vahiduddin, 1990, 6). This is why no religious community may insist its own religious tradition is superior (Ateş, 1998, 10).

There is, finally, a consensus among the Muslim pluralists also regarding the fundamental assumption of the incomprehensibility of the actual truth or God as such. Accordingly, the human being is by nature a finite and needy being in all respects, whose desire for knowledge of the absolute truth remains unfulfilled in all legitimacy - not because there is no absolute truth but because, as a finite being, he possesses neither the means nor the ability to harness for himself something of the Infinite and Wholly Other. Referring to sura 112:4, which underscores God's uniqueness, Madjid argues that the only absolute is God who, by definition, remains fully incomprehensible to relative beings, which includes human beings (Madjid, 2019, 44). All efforts to understand absolute reality, however good and proper they may be, are therefore inadequate for getting hold of the truth entirely (Aydın, 2019, 255), for God transcends our ability to comprehend it (Askari, 2002, 13).

The recognition of human perspectivity, especially in reference to the human ability to know the truth is a necessary condition for the cultivation of a pluralist attitude, and not only in the religious context. Only those who are aware of their own perspectivity can also encounter other approaches to truth in a respectful way and accord them the same legitimacy as their own. This may be why pluralist approaches have developed primarily in Islamic mysticism, i.e., Sufism. The humble attitude of the mystics (sufis) regarding absolute truth helped many of them renounce any claims to superiority and to see the good in other religions (Frembgen, 2013, 212). Even if this does not apply to all currents within Islamic mysticism - since it is as complex and multifaceted as Islam itself - Sufism can nevertheless claim to have cultivated pluralist approaches before the modern era 
and have thus become a source of inspiration for Muslim intellectuals today (ibid., 211).

My remarks up to this point show that a respectful approach to religious plurality from an Islamic perspective is possible, though it is not self-evident. It is the product of a continuous struggle with Islam's own sources and doctrines as well with competing approaches that see a watering down of Islam's identity in the pluralist attitude and have the stronger argument when it comes to a literal exposition of the Islamic texts. My remarks up till now are all the more important for the theological situation of Islamic religious education. Finally, theology - in this case Islamic theology - is one of its central partner sciences. We will discuss the concrete consequences of the understandings of the relation here for religious education briefly in the next section.

\section{Pluralist Approaches for Islamic Education}

As already maintained at the beginning of this essay, the reality in which we live is increasingly stamped by worldview and religious plurality. If this plurality was still a limited peripheral phenomenon in a few large European cities a few years ago, it has in the meantime become an everyday reality in Western Europe. We encounter the cultural and religious other everyday - at work, at school, while shopping, and in the neighbourhood. Different cultures and religions are so closely interwoven that they can only be ignored with great difficulty. This new situation, which will crystalise further in light of current developments, confronts us with greater challenges than ever before. In particular, the plethora of cultures and religions, to use Mirjam Schambeck's words, raise the question of "How the confrontation with these cultures can succeed so that religions are taken seriously in their plurality, and this plurality becomes fruitful for good human co-existence" (Schambeck, 2013, 163). Thus, in addition to religious competence, the approach to other religions becomes a "fundamental competence for living in our world” (Schluß, 2015, 415). This approach becomes a fundamental competence not only because it is simply a condition for peaceful co-existence but also a condition for success in the international labour market where intercultural and interreligious sensitivities are always in demand.

At this point, the appeal to religion, as one of the basic pillars of society, offers to provide plausible answers to the question of the shape of a beneficial coexistence - namely, in the area of religious education and religious pedagogics associated with that. Given the changed circumstances, new approaches are needed to meet these circumstances and to enable a dialogue based on mutual dignity and willingness to learn, which not only serves the cultivation of a plu- 
ralist society but also constitutes the foundation of a pluralist legal order. The new relations and the demand for the development of corresponding abilities and skills cannot be met by antiquated attitudes (Kunstmann, 2010, 262).

The appreciation of plurality and the concomitant differences is a matter of perspective and attitude - thus a perspective fixated on compliance will either conceal the differences or perceive them as a shortcoming (Kraml \& Sejdini, 2015, 29). Precisely here religious education has to do justice to its role as the guide of processes of transformation and change if it is to make the promotion of an ability to deal with contingency and plurality its primary concern. The goal of religious education and thus of religious pedagogics cannot be to simply pass on theological truths; rather, as the newest theological discipline and the one most affected by change in the modern world, it is obligated not only to cultivate religious plurality but to make it the constitutive aspect of religious education (Kunstmann, 2010, 13). Finally, school is not only concerned with passing on material but also with teaching and living co-existence and thus lays the cornerstone for a respectful attitude for social life (Delory-Momberger, 2009, 298).

This situation presents Islamic religious education with the task of choosing and establishing a religious educational approach from among the theological approaches discussed above. The approach it chooses is the one that will most likely introduce young people to a respectful attitude towards religious plurality and thus create the conditions for a flourishing co-existence and the willingness to learn from each other.

The success of such a process of education in the sense of conveying an open attitude that meets the goal of religious education and is viable theologically and in a religious educational sense depends of course on taking a series of aspects into account. Here, this co-existence is threatened with the danger that it is not grounded in the conviction that plurality is willed by God and that all religions are in essence equal. Rather, at best it may be based on one of the current circumstances of forced tolerance of other religions. But tolerance alone of other religions cannot be the ideal of religious education, for it implies the inferiority of that which is to be tolerated. To guarantee a genuinely respectful approach to plurality, processes of religious education should be shaped according to some fundamental assumption. We will look at these below.

Concretely, the following perspectives emerge from the proposed approach by Muslim pluralists for Islamic religious education. These perspectives will make this approach fruitful for this area.

- The distinction between Islam as a religion, as we have known it since the Prophet Muhammad, and islam in the sense of devotion to God can be found in all religions but also needs to be made explicit in the framework of religious education. Based on many Qur'anic statements and supported by a 
plurality of scholars, this approach offers an incontrovertible foundation for a respectful attitude to other religions. Here, on the one hand, the common origin and the essence of religion comes to the fore; on the other, it recognises that other religions can lead to salvation or are not excluded from it - and thus it also revises the widespread assumption by institutionalised Islam that all other religious traditions are null and void as potential paths to salvation. In fact, the appeal is thus issued to reflect on the common orientation to God instead of on formal differences. The perception of one's own religion as the consummation of the monotheistic tradition should not lead to denying other religions of the same tradition the right to existence. Rather, one's own religion should be seen as an alternative attempt to understand absolute truth anew in a specific historical context and to revitalise the common spirit of this religious tradition. Such an approach should be anchored in a confessionally oriented religious education to avoid slipping into exclusivism.

- This presupposes a corresponding approach to the Islamic sources, above all, the Qur'an as the revelation of God. And here we arrive at another important point that is of decisive significance for a respectful attitude from the perspective of religious education (Sejdini, 2016a). This aspect plays a more fundamental role than the others because the Qur'an is the court of appeal for all theological and religious educational reflections. This central source is not to be understood as a book of instructions but as communicative discourse. As such, it is not just that we need to take its context of origination and the needs of its first addressees into account in our interpretation. Rather, these factors have left a decisive imprint on the Qur'an itself. It is precisely with a view to the processes of religious education, the communicative aspect of the Qur'an is of enormous significance. On the one hand, this mirrors the Qur'anic reality, which is dialogical through and through. On the other hand, a way is therefore opened up for a constantly new interpretation of the fundamental Qur'anic idea that can also make the Qur'an an inexhaustible source of inspiration for religious education outside its context of origination as well. In contrast, a literal interpretation, which we see in most conservative circles, would thus not only create misunderstandings but also turn out to be an insurmountable obstacle to respectful co-existence in religious plurality. In addition to the communicative approach to the Qur'an, its ambivalent nature is also to be considered in the conception and shaping of the processes of religious education. Both aspects 
have to be taken into consideration in religious education so that the pluralist potential of the Qur'an can unfold. ${ }^{4}$

- Connected with that - as another central aspect - is the thematisation of the fact that the absolute truth can be experienced. Even if it is generally assumed that God, because of his uniqueness, transcends all human ideas and that ideas about God say more about people than about God, the perspectivity and fragmentariness of all human attempts to experience God have to date not been taken sufficiently into account in religious education. All too often, the established teachings and interpretations of Islam are presented as unshakable eternal truths which means that all statements by other religions are heresies. This obtains, moreover, not only for the teachings of other religions but also for intrareligious deviations that are occasionally combatted more intensely than other religions. In the meantime, the notion of someone who is constantly searching, who sees her goal not in possessing the truth but - guided by humility given the infinity of the eternal - to strive unceasingly for it seems to be a meaningful one for religious education.

- As a final point, which is also connected with the preceding, the appropriate approach to the Islamic tradition as an important source of inspiration for Islamic theology and religious education should be mentioned (Sejdini, 2018). The Islamic tradition here means those approaches in theological and religious education that have been developed by Muslim scholars in a specific era and therefore necessarily accord with the spirit of the time. Precisely because these approaches do not arise in a vacuum, they must be linked up with one's own - in this case religious educational - tradition. Those models that are viewed as universally valid and, according to many conservative circles, need to be revived must be examined as well. This also concerns religious educational approaches to dealing with religious plurality that arose in a completely different context.

- These accomplishments are by no means irrelevant. Their significance, however, does not lie in their alleged function as models that should be followed by all succeeding generations. Rather, it lies in the evidence they produce that a tolerant attitude was more widespread among Muslims at that time than in other cultures and religions. In that way they could stimulate efforts to again take up the role of trailblazer and to reclaim their erstwhile position in the world as an important source of the recognition and promotion of religious plurality. In this context, the uncritical, glorifying adherence to the

4 A systematic analysis of hadith literature is of enormous importance here. 
past would be damaging not only to the present but also to these models that doubtless had their merits in their respective contexts of origination and contributed to peaceful co-existence. An approach or model that has proved itself in a specific time and under specific conditions can still have the opposite effect under changed conditions - which does not change the fact that it was the best possible option at that time. From this perspective, Aziz al-Azmeh is right when he says:

Muslim historical experiences can and indeed do inspire, but they inspire aesthetically, and perhaps in a general way normatively. What they cannot be allowed to do, however, is inspire the desire for their repetition. (Al-Azmeh, 2009, 15)

In other words, religious education also needs to take the dictum to heart that tradition does not offer ashes but passes on the fire.

The above-mentioned points, which can be expanded or completed, should offer stimulation for discussion and reflection - of course in the awareness of all the difficulties that are to be overcome in the establishment and implementation of pluralist approaches in religious education. That this is possible on the basis of the Islamic sources is indisputable, given the Qur'anic statements and the new pluralist approaches by Muslim scholars. Whether these approaches are rejected as a watering down and relativisation of the Islamic faith and Islamic identity or are taken sufficiently into account in present Islamic religious educational approaches is an open question (Vahiduddin, 1990, 6). What is needed above all is courage - according to the Egyptian philosopher Hassan Hanafi (b. 1935) "to formulate an alternative to what has been entrusted to us for a thousand years and is familiar" (Hanafi, 2013, 17). 
